Vol. 44, N. 4 : pp. 383 - 394, December, 2001

ISSN 1516-8913 Printed in Brazil

\title{
Morphology and Anatomy of the Flowers of Trichilia catigua A. Juss., T. elegans A. Juss. and T. pallida Sw. (Meliaceae)
}

\author{
Luiz A. de Souza*; Ismar S. Moscheta; Káthia S. M. Mourão and Adriano Silvério \\ Universidade Estadual de Maringá, Departamento de Biologia, Avenida Colombo, 5790, 87020-900 Maringá - PR, \\ Brazil
}

\begin{abstract}
Morphological and structural features of flowers of Trichilia catigua A. Juss., T. elegans A. Juss. and T. pallida Sw. (Meliaceae) are presented here with the purpose to stimulate future reproductive and preservation studies of these brazilian native species. Anthesis occurred from April to August in T. catigua, January to May in T. pallida and September to January in T. elegans. Sepals and petals presented a papillose and pilose epidermis and a parenchymatous mesophyll. Male flowers presented pistillodes with abortive ovules and a staminal tube with tetrasporangiate anthers. Anther wall had a papilose epidermis, a fibrous endothecium, two middle layers and a secretory tapetum. Female flowers presented antherodes and bi - or tricarpellate syncarpous pistils. Ovary had a simple structure with anatropous, bitegmic ovules. Style was hollow or solid and the stigma was constituted by unior bicelullar trichomes. Strictly dioecious specimens were not found in the study area.
\end{abstract}

Key words: Trichilia, Meliaceae, floral morphology and anatomy, flowering

\section{INTRODUCTION}

Trichilia P. Browne, belonging to the Meliaceae family, accounts for about 70 species distributed throughout Tropical America. The species frequently present unisexual (bisexual to a lesser degree) flowers in dioecious plants and there are even records of polygamous plants (Pennington, 1981; Klein, 1984). In the forest remnants in and near Maringá, Paraná State, Brazil, three species of Trichilia occur: T. catigua A. Juss (catiguá), T. elegans A. Juss. (pau-de-ervilha) and T. pallida Sw. (baga-de-morcego). These species have a wide distribution in South and Central America. The first two are more abundant in southern Brazil and the last one is dispersed throughout Brazil and be very common in the southeastern gallery forests (Pennington, 1981; Klein, 1984).
The flowers of Trichilia species are not well known in their anatomical aspects. However, anatomical features such as ovaries and ovules in T. grandifolia Oliv., T. elegans A. Juss., T. pallida Sw. and T. catigua A. Juss. are described by Boesewinkel (1981), Beltrati (1984), Beltrati and Brunini (1988) and Moscheta (1995), respectively. Morphological descriptions of flowers are limited to the works of Pennington (1981) and Puentes et al. (1993). Studies about floral biology include works of Styles (1972), Opler and Bawa (1978) and Opler (1983).

The process of the human occupation of Paraná decimated the original forests of the state. Forest coverture has reduced from $83.41 \%$ to approximately just $7 \%$ presently, most of which is concentrated in the "Serra do Mar" and Iguaçu National Park. In the northwest region of Paraná,

* Author for correspondence 
the situation is more critical, with less than $1 \%$ of the forest remnants located in units of conservation and on the islands in the Upper Paraná River which are subject to flooding (Ipardes, 1992; Campos, 1997).

With the purpose of understanding the differentiated behavior of Trichilia plants (dioecious, monoecious and polygamous) recorded in the literature and stimulating future reproductive and preservation studies on Paraná's forests, morphological and anatomical features of the flowers of Trichilia catigua A. Juss., T. elegans A. Juss., and T. pallida $\mathrm{Sw}$. are presented and discussed.

\section{MATERIALS AND METHODS}

The "Horto Florestal Dr. Luiz TeIxeira Mendes", where the species were observed and studied, is situated in the city of Maringá, Paraná State, Brazil between the meridians $51^{\circ} 30^{\prime}$ and $54^{\circ} \mathrm{W}$ and the parallels $22^{\circ} 30^{\prime}$ and $24^{\circ} 30^{\prime} \mathrm{S}$, with an average altitude of 556 meters. In this forest remnant, there are shrubs and small trees of Trichilia elegans A. Juss., and small trees of $T$. catigua A. Juss. and T. pallida Sw., whose vouchers were deposited in the Herbarium of the Universidade Estadual de Maringá, under numbers HUM 5111, HUM 2210 and HUM 197, respectively.

The flowering time for the species was followed in at least five previously marked specimens between April 1999 and June 2000 by means of weekly observations. During this period, flowers were collected before and after the anthesis, immediately analyzed in the laboratory and fixed in FAA 50 and FPA 50 (Johansen, 1940). The anatomical study of the collected botanical material was sectioned by microtome techniques in paraffin wax (Johansen, 1940) or methacrylate (Ruetze and Schmitt, 1986). Erlich hematoxylin and safranin were used for staining (Johansen, 1940). In addition, temporary and semi-permanent slides obtained from hand sections and stained with safranin and astra blue were made. The following stains were used for specific color tests: phloroglucinol and sulfuric acid, Sudan IV and IKI for lignins, lipids and starch, respectively (Johansen, 1940; Berlyn and Miksche, 1976).

\section{RESULTS}

\section{Morphology}

The flowering time for the species can be long, as in T. catigua, where the floral buds can stay on the plant for five to six months before the anthesis process begins. In $T$. pallida and T. elegans the floral buds stay on the plants for about two months. The anthesis occurred from April to August in T. catigua, from January to May in $T$. pallida and from September to January in $T$. elegans.

The flowers of the species were minute, approximately three millimeters long in $T$. elegans, about four millimeters in T. catigua and a little more than five millimeters in $T$. pallida. These flowers occurred in axillary panicles in the three species. However, the inflorescence in T. catigua was congested and in $T$. pallida small racemes with short axes can occur. The flowers presented a short pedicel, at whose base occurred a reduced bract and two bracteoles with the same shape, but smaller dimensions. They were still dichlamydeous, actinomorphic and unisexual (Figures 1 and 2).

The synsepalous green calyx had four sepals in $T$. catigua and T. pallida (Figure 21) and five in $T$. elegans. In T. catigua the sepals were more pilose and reduced. The corolla presented four separate petals (Figure 21), except in T. elegans, which had five separate petals, white to yellow in color and lanceolate (Figures 3 to 5) to ovate in shape. The petals of $T$. elegans presented only one central vein, which branched out into secondary veins of smaller caliber (Figure 4). In T. catigua the petals showed two main veins, which emited several branches (Figure 3). In T. pallida, several veins started from the petal base. The central vein presented larger caliber. Eventually, these veins branched out (Figures 5 and 7).

In male flowers the androecium was constituted by a staminal tube, which had tetrasporangiate anthers (Figure 2). The tube apex of T. elegans had ten anthers alternating with thin and pilose extensions. There were seven or eight alternating anthers with edges in T. catigua. These seven or eight pilose anthers were attached by small filaments to the tube. All the anthers had longitudinal opening. The androecium presented the same morphology in 
female flowers, but the anthers lacked pollen (Figures 1 and 20).

The gynoecium in female flowers presented a syncarpous pistil. The conical ovary (Figure 1) had three carpels and locules, two ovules per locule with axile placentation, short style and prominent stigma. Some variations were also found in the studied species: in T. elegans the gynoecium might have present two or three carpels and there were many shaggy trichomes in the ovary of $T$. pallida. In male flowers, the gynoecium was represented by a pistillode with abortive ovules (Figure 2).

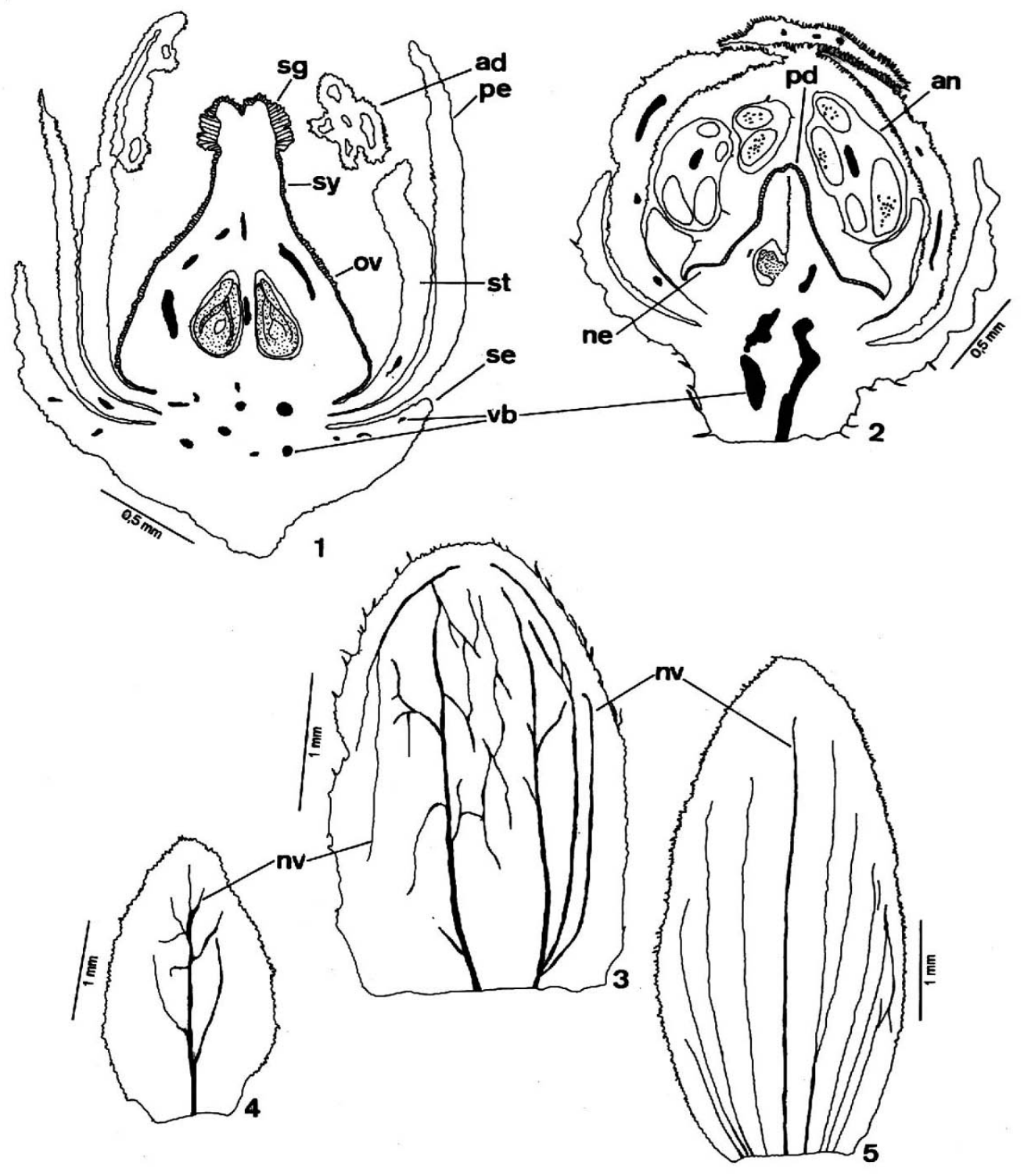

Figure 1-5. 1-2 - Female flower of T. elegans and male floral bud of T. pallida in longitudinal section, respectively; 3-5: Cleared petals of T. catigua, T. elegans and T. pallida, respectively. (ad=antherode; an=anther; ne=nectary; $\mathrm{nv}=$ =ein; ov=ovary; $\mathrm{pd}=$ =pistillode; $\mathrm{pe}=$ petal; $\mathrm{se}=$ sepal; $\mathrm{sg}=$ stigma; $\mathrm{st}=$ staminal tube; $\mathrm{sy}=$ style; $\mathrm{vb=vascular}$ bundle)

Nectaries were present only in T. elegans and $T$. pallida (Figure 2). The nectaries in T. elegans, not always present, occurred as a disk-like structure involving the base of the ovary. In T. pallida the nectaries were formed at the base of the ovary and the staminal tube. 


\section{Anatomy}

The sepals of the species had a single, papillose epidermis (Figure 6), with unicellular trichomes of thin extremity in T. catigua and T. pallida. The parenchyma cells of the mesophyll showed thin walls and vary in size and shape. There were also secretory cavities and wide secretory cells (Figure 6). Vascularization was made by a central collateral vascular strand, next to others with small dimensions.

The petals had a uniseriate papillose epidermis, with trichomes, stomata (Figures 7 to 13) and cuticle, which could also be ornamented (Figure 11). The papils occurred frequently in the epidermis of the three species and showed thick cellular walls (Figures 8 to 11). The trichomes could be uni or pluricelullar, with thin or thick cellular walls and pointed, or more or less rounded extremities (Figures 10 and 12). They were common in the petal edges. In the floral buds there was a perfect adjustment among the trichome epidermes with contiguous petals (Figure 13). The mesophyll was parenchymatic and constituted by cells with thin walls and by secretory cells and cavities. This region had few layers in T. catigua and T. elegans (Figure 9) and many in T. pallida (Figure 8). The presence of calcium oxalate druses was notable in the parenchyma cells of $T$. catigua and $T$. elegans. There was a central collateral vascular strand and others of small dimensions immersed in the mesophyll (Figure 7).The nectaries were constituted by a single epidermis with thin-walled cells and non-glandular unicellular trichomes with relatively thick walls (Figure 15), and by a secretory parenchyma where the phloematic vascular tissue and secretory cells and cavities stood out (Figure 14).

The male flowers of $T$. catigua and $T$. elegans presented androecium constituted by a staminal tube with a unilayered epidermis and prolonged non-glandular unicellular trichomes. The epidermal cells were papillose and showed a relatively thick and ornamented outer periclinal wall. Below the epidermis there was a homogeneous parenchyma with thick-walled cells (Figure16). It presented secretory cells and cavities and vascular bundles; one for each anther (Figure 21). The vascular bundles of the tube could be collateral or concentric. The androecium of $T$. pallida also had a staminal tube, but differed from the other two species by nectaries and papils at the base and trichomes in the proximities of the anthers; however, in T. pallida the papils did not show a thick or ornamented wall. The wall of the immature anther presented a single papillose epidermis, endothecium with thin-walled cells, slightly prismatic in shape, two middle layers and a secretory tapetum with binucleate cells (Figure 18). In the mature anther, the endothecium cells acquired thickenings on the anticlinal walls and on the inner periclinal wall. The middle layers and the tapetum began a disintegration process, were flattened and crushed (Figure 19). The pollen grains remained united in tetrahedron-type tetrads (Figure 17).

In female flowers, the antherodes without pollen had a papillose epidermis at maturity and an endothecium with parietal thickenings. The middle layers and the tapetum disintegrated in this phase (Figure 20). The only pistil in female flowers had an ovary with a uniseriate outer epidermis, which showed stomata and a cuticle. The epidermal cells varied from tabulate to prismatic in shape. The epidermis was glabrate and papillose in T. elegans and pilose in $T$. catigua and $T$. pallida. The trichomes, very abundant in these species, were non-glandular, unicellular, presented thick cellular walls and thin extremities. In the multilayered parenchyma mesophyll there were secretory cells and cavities, notably numerous in $T$. elegans. A single and glabrate epidermis covered the ovarian cavity and presented cells tabulate to slightly prismatic in shape. Both the subepidermal layers (Figure 30) as the ventral epidermis of T. elegans and T. pallida could undergo periclinal divisions in the preanthesis stage. Ovarian vascularization was made by differentiated vascular bundles or by lateral, ventral or marginal and dorsal procambial bundles, in accordance with carpel number. The septs, which separated the locules, were interrupted in the ovary apex and joined the locules to each other (Figures 21 and 22).

The pistil still had a short style with an epidermis similar to that of the ovary, which covered the parenchyma tissue, where there were vascular bundles and central transmitting tissue (Figures 23 to 25 ).

The vascular bundles varied in number, three being of larger dimension (one for each carpel) and other smaller ones might eventually be present (Figures 23 and 24). In T. elegans specimens with two carpels, there were only two vascular bundles (Figure 25). The transmitting tissue was formed by 
the epidermis and the secretory subepidermal layer which were arranged in the central region of the style as three small edges (Figures 23, 24 and 29) or two in $T$. elegans specimens (Figures 25 and 28).
The style in T. catigua and T. pallida, represented by a small rift, was hollow (Figures 23 and 29). In T. elegans, however, a central rift occured in the middle region of the style only, therefore presenting a solid nature in the base and in the apex (Figures 25 and 28).

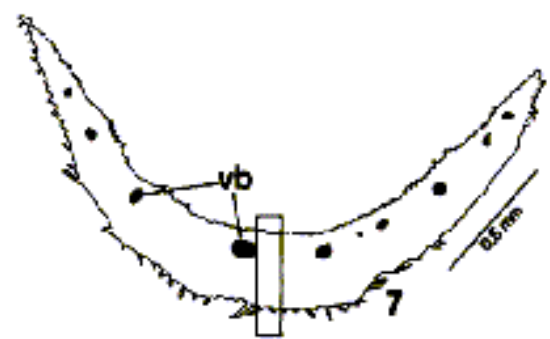

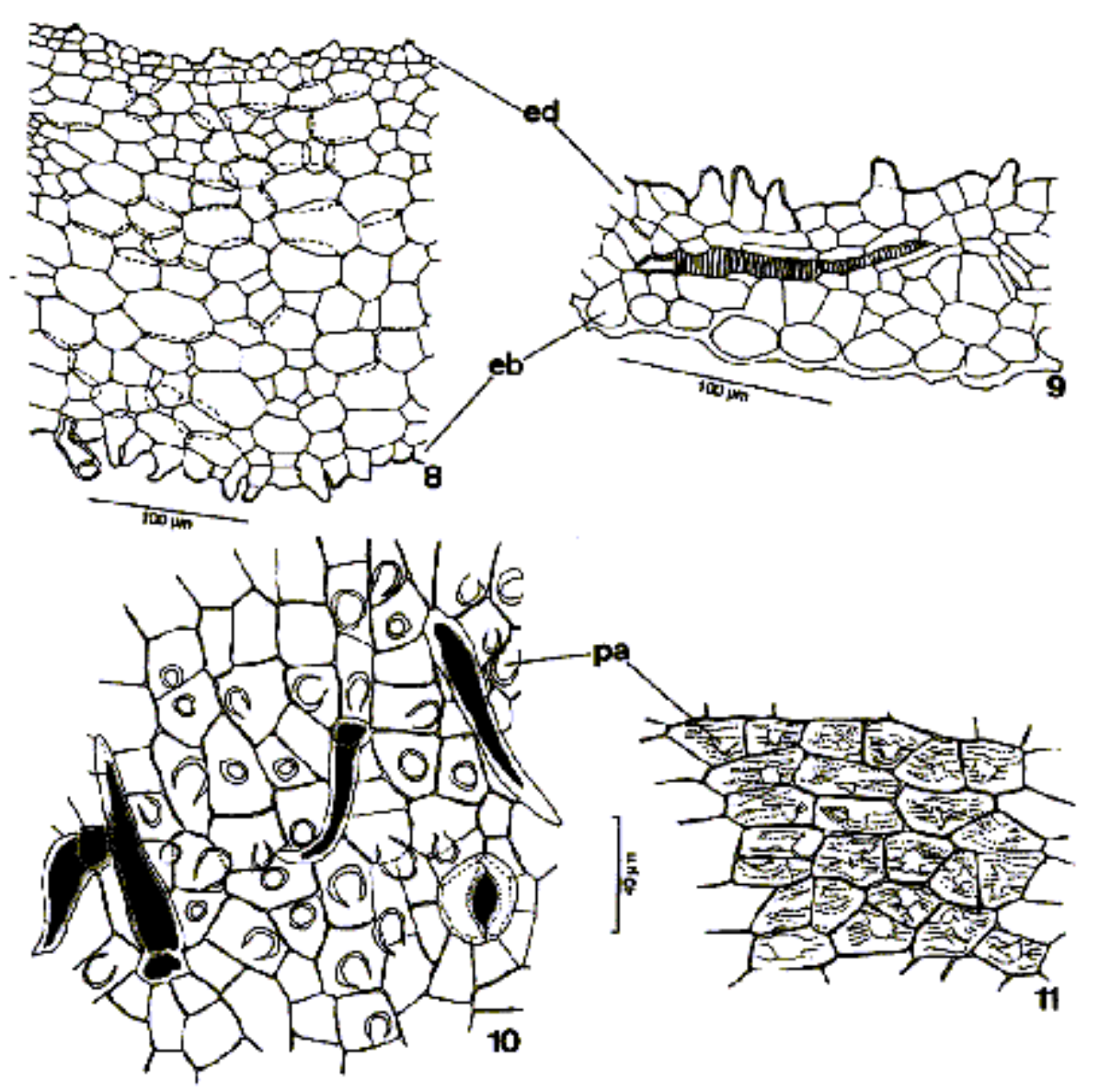

Figure 6-11. 6 - Detail of the floral bud sepal of T. elegans in cross-section; 7-8: Diagram and detail of the floral bud petal of T. pallida in cross-section; 9: Detail of the petal of T. elegans in cross-section; 10-11: Detail of the adaxial and abaxial surface of the petal epidermis of $T$. pallida and T. elegans, in frontal view, respectively, ( $\mathrm{eb}=$ abaxial epidermis; $\mathrm{ed}=$ adaxial epidermis; $\mathrm{pa}=$ =pidermal papillae; $\mathrm{sc}=$ secretory cell; $\mathrm{vb}=\mathrm{vascular}$ bundle)

The transmitting tissue traversed the whole style and reached the apical region of the ovarian locule. The stigma presented unicellular trichomes, more frequent, and bicelullar; these trichomes came from the immature epidermis of the stigma, whose cells could undergo periclinal divisions and posterior lengthening (Figures 26 and 27). 

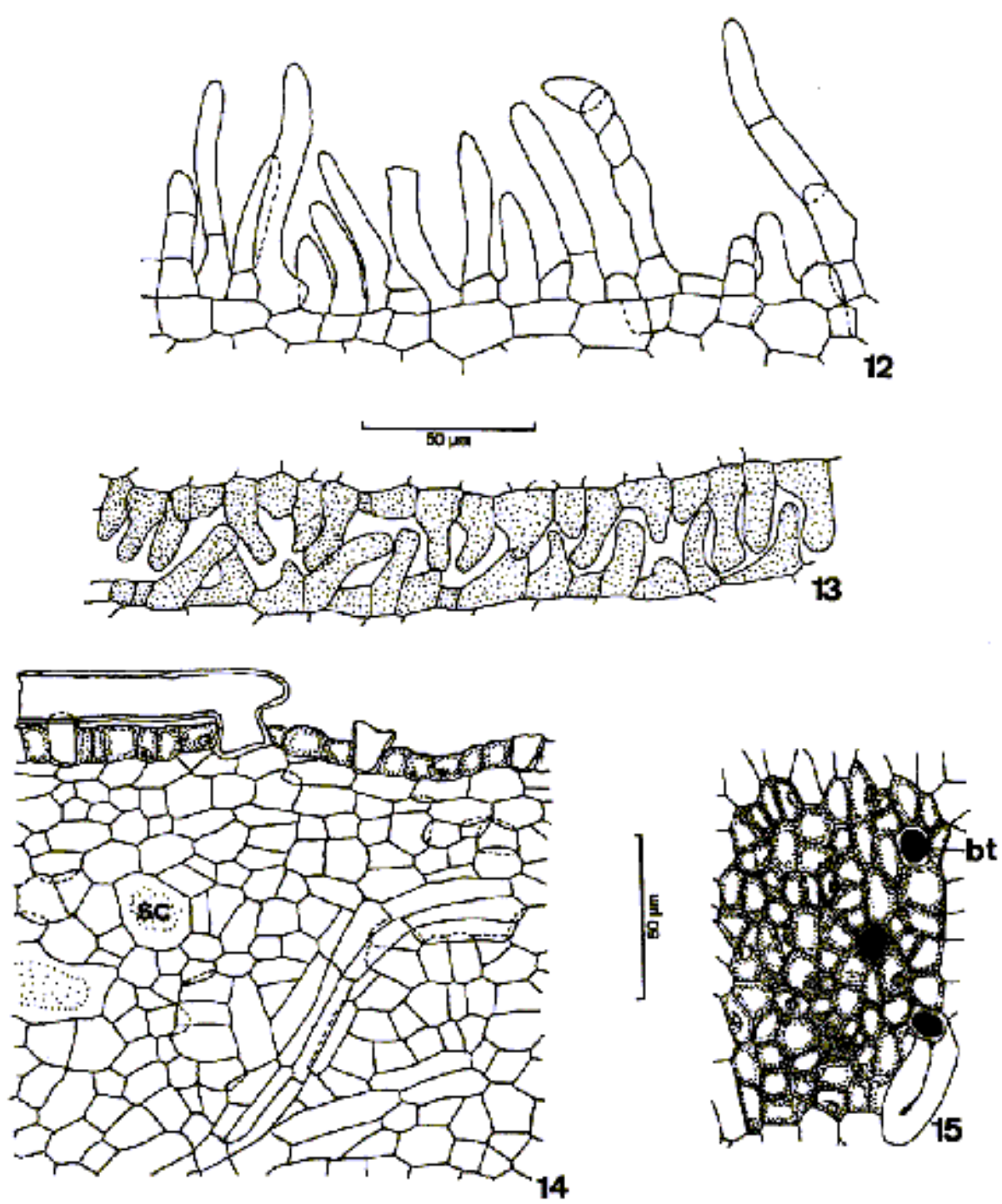

Figure 12-15. T. pallida. 12: Detail of the abaxial surface of the petal epidermis, in longitudinal section, showing uni and multicellular trichomes; 13: Detail of the contiguous epidermis of the petals, showing the papillaes; 14: Structural details of the nectary; 15: Nectary epidermis in frontal view. (bt=trichome base; sc=secretory cell) 

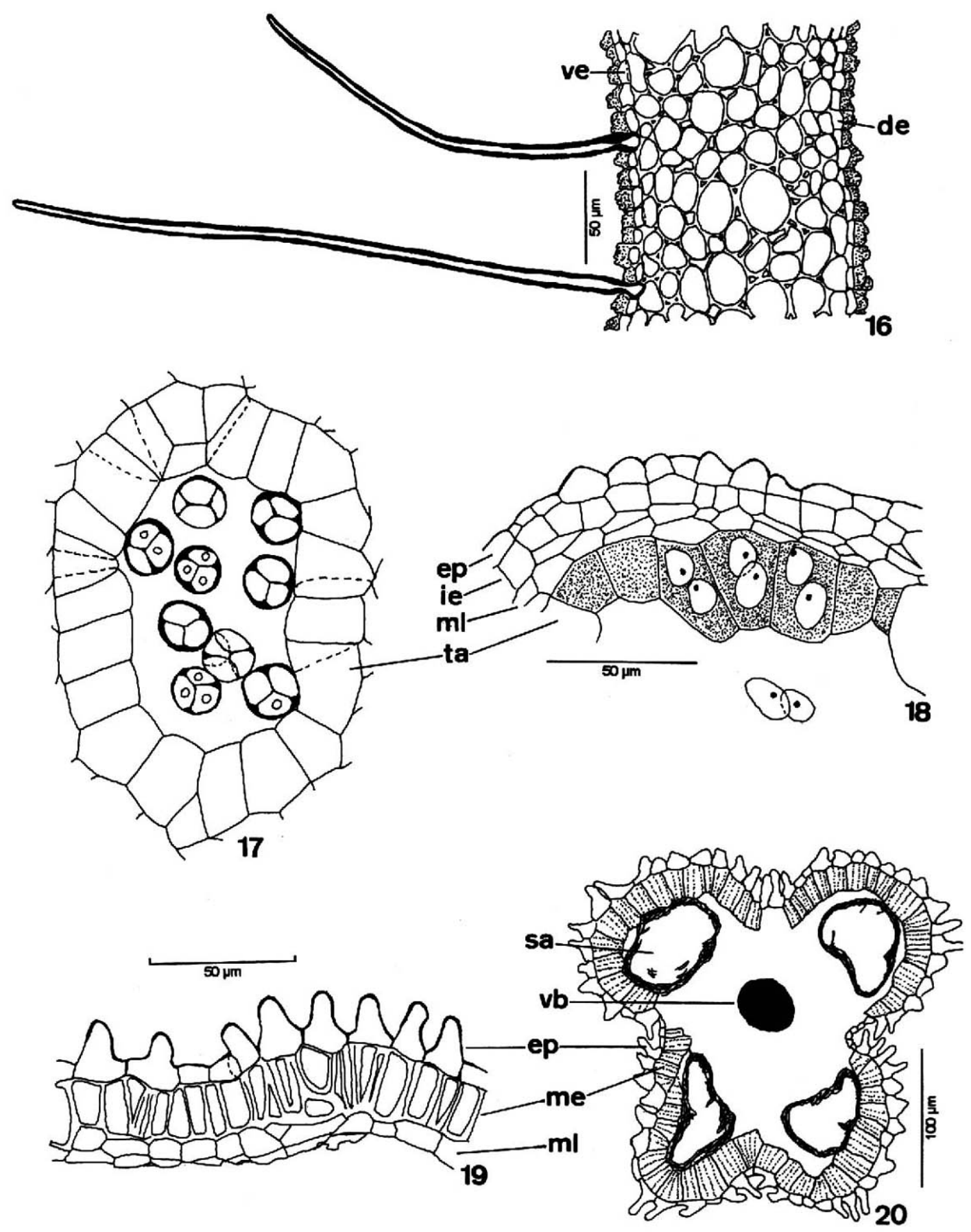

Figure 16-20. 16 - Structural detail of the staminal tube wall of T.catigua; 17: Detail of the secretory tapetum and the microspores in tetrads in T. pallida. 18-19: Detail of the young and mature anther wall in T. pallida and T. elegans, respectively; 20: Diagram of the antherode in T. elegans, in cross-section. (de=dorsal epidermis; ve=ventral epidermis; ep=epidermis; ie=immature endothecium; me=mature endothecium; $\mathrm{ml}=$ middle layers; as=pollen sac; ta=tapetum; $v b=$ vascular bundle) 

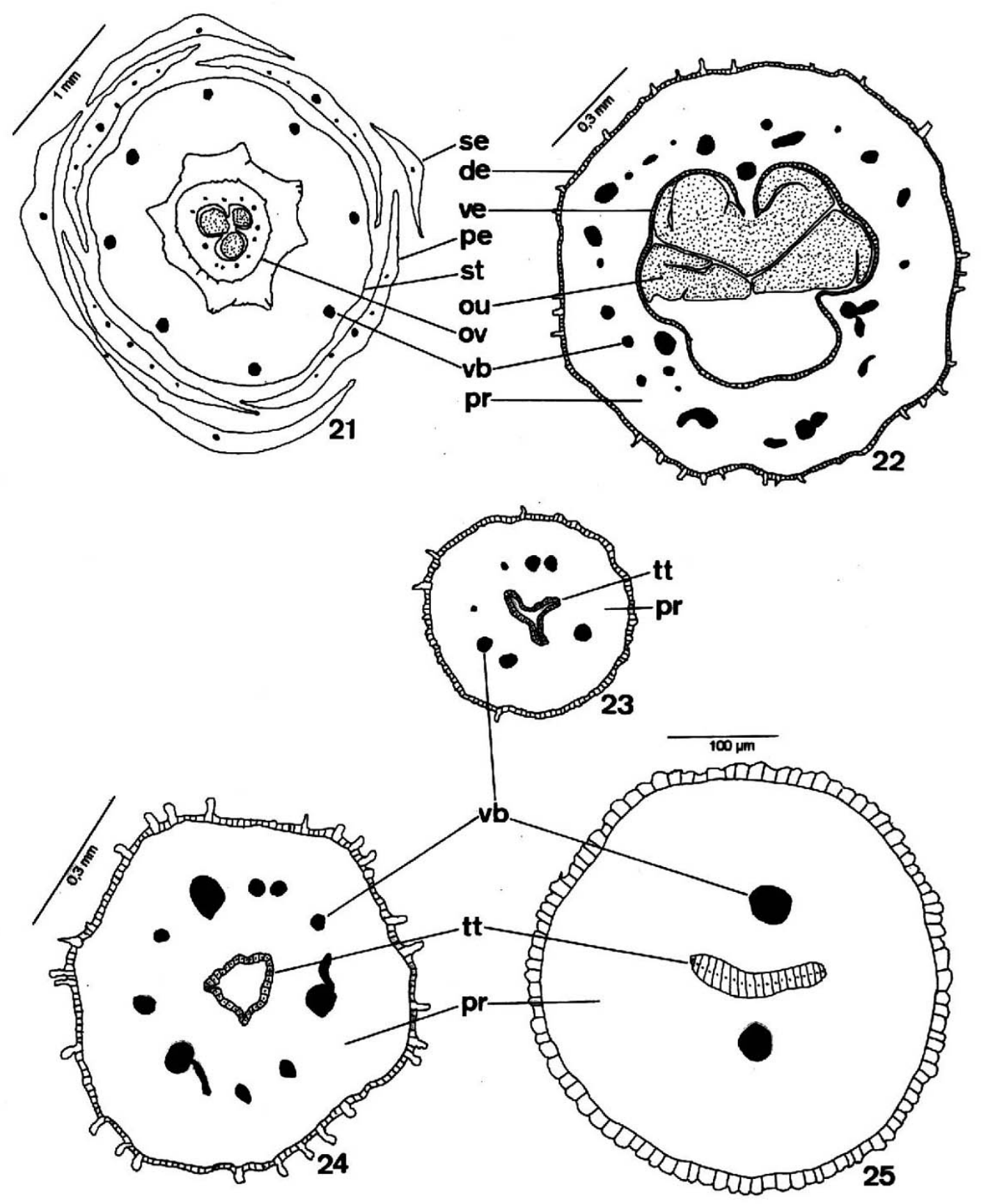

Figure 21-25 - Diagrams of the cross-sections. 21: Flower of the T. pallida; 22: Upper portion of the ovary in $T$. catigua. 23-24: Basal and apical portion of the hollow style in T. catigua; 25: Solid style in T. elegans (de=dorsal epidermis; ve=ventral epidermis; ou=ovule; ov=ovary; pe=petal; pr=parenchyma; se=sepal; st=staminal tube; $\mathrm{tt}=$ transmitting tissue; $\mathrm{vb}=$ vascular bundle)

The ovules were anatropous and bitegmic and had several cellular layers between the nucellus epidermis and the embryo sac (Figures 31 and 32). The integuments were multi-layered and the number of layers varied from three to eight in the outer integument and three to seven in the inner integument (Figure 31). Two synergids of prolonged contour were observed in the embryo sac, where its filiform apparatus and the two polar nuclei were notable (Figure 33).

The ovules had an obturator of placental origin (Figure 32). The pistillode of the male flowers had a structure similar to the pistil of the female flowers, but with abortive ovules (Figure 2). 

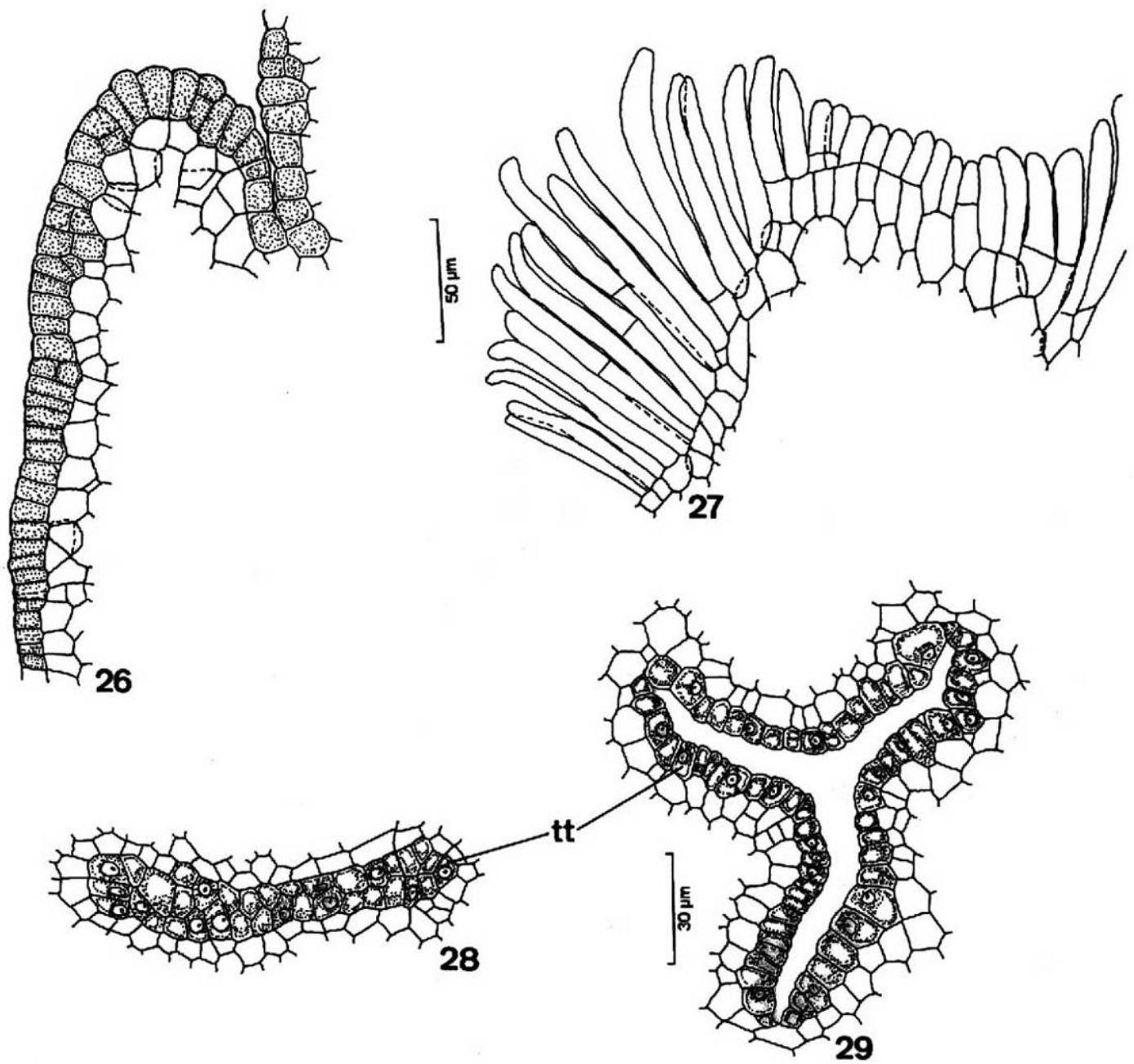

Figure 26-29. 26-27 - Details of the epidermis in the young and mature stigma of $T$. pallida and $T$. catigua, respectively; 28 - 29: Detail of the transmitting tissue of the solid and hollow style of T. elegans and T.catigua, respectively. (tt=transmitting tissue)

\section{DISCUSSION}

Pennington (1981) and Klein (1984) recorded for Trichilia generally unisexual flowers in dioecious plants and less frequently bisexual and then polygamous plants. The flowers of $T$. catigua, $T$. elegans and T. pallida were unisexual, but strictly dioecious specimens were not found in the studied area, all of them being monoecious to a greater or lesser degree. The nectary presence in Trichilia species in the form of a thick ring around the ovary seemed to be common (Pennington, 1981), as verified in $T$. elegans and T. pallida; although in the latter species it was fused to base of staminal tube.

According to Agthe (1951), the sugar concentration of the nectar is correlated with the type of vascular tissue that reaches the nectariferous tissue. In present study, the vascular tissue of the nectaries of the Trichilia species consisted only of phloem. It meant that the nectar sugar contents of these species could be high. This supposition was in accordance with Agthe (1951) who found similar results in other species from different families. 

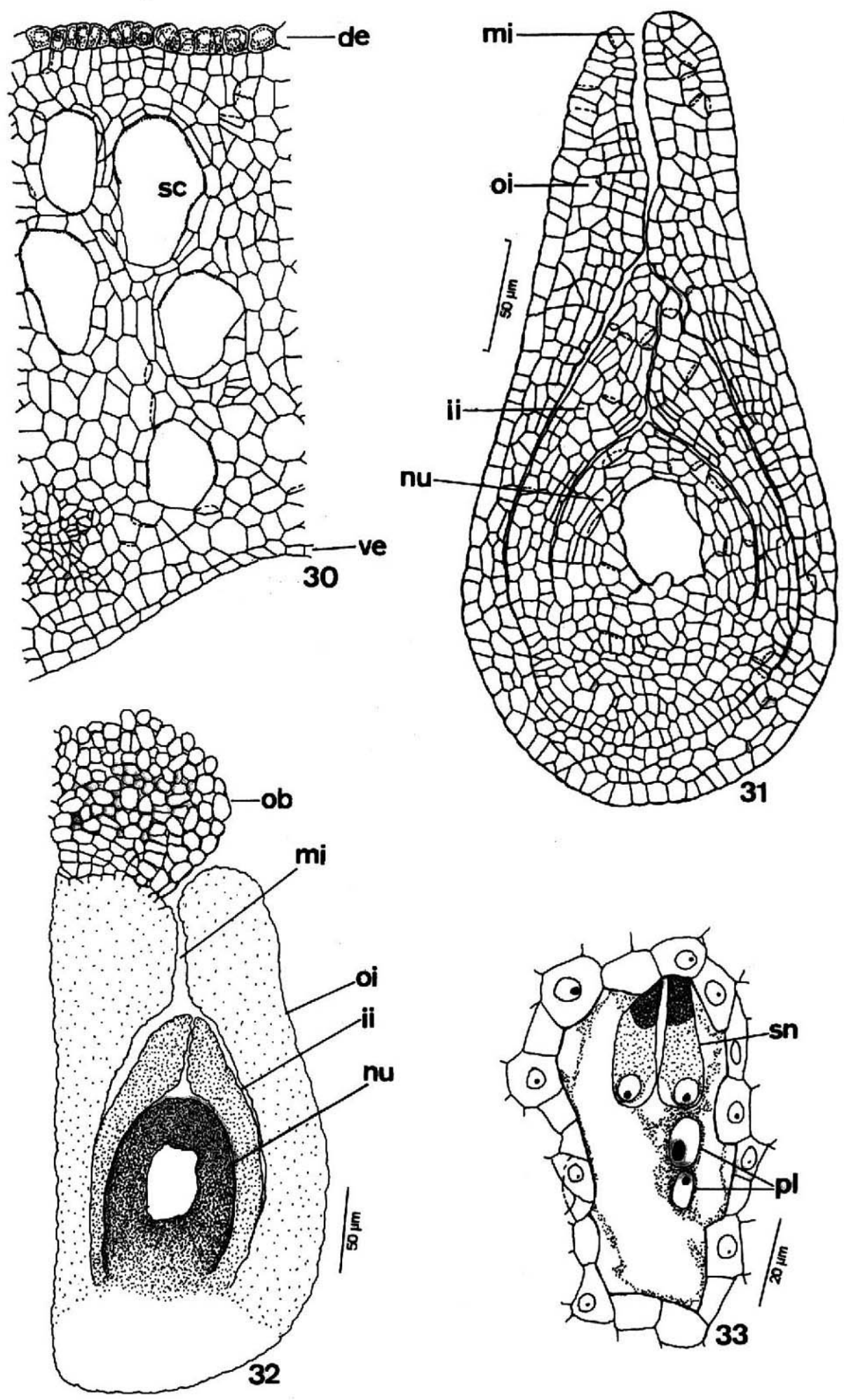

Figure 30-33. 30 - Detail of the ovary wall of T. elegans; 31: Longitudinal section of the ovule of T. elegans; 32 : Diagram of the longitudinal section of the ovule of the T. catigua; 33: Embryonic sac of $T$. elegans showing synergid cells and polar nuclei. (de=dorsal epidermis; ve=ventral epidermis; ii=inner integument; mi=micropyle; $\mathrm{nu}=$ nucellus; ob=obturator; oi=outer integument; $\mathrm{pl}=$ polar nuclei; $\mathrm{sc}=$ secretory cell; $\mathrm{sn}=$ synergid cells) 
The gynoecium structure is very important in the reproductive process of the studied species, from the arrival of the pollen on the stigma until the occurrence of the syngamy inside the ovule. The receptive stigma surface of the species constituted by unicellular or bicellular trichomes seems to fit in Group III of Heslop-Harrinson and Shivanna (1977). This group is characterized by papillae or trichomes of reduced or medium extension. The transmitting tissue of the style, where the pollen tube was developed, was mainly epidermal and limited to a small central cavity in T. catigua and T. pallida; but it was solid at the base and apex of the T. elegans style. This meant that the pollen tube developed along the style on the transmitting tissue surface in the first two species or penetrated this tissue growing among the cells in T. elegans. When in the apex region of the ovary, the septs were interrupted, facilitating communication between the locules. This could favor eusyncarpy, in which the pollen tube could fertilize an ovule of any carpel -- a process verified in the Rutales, very physiologically important and with evolutionary consequences (Carr and Carr, 1961). Finally, the obturator was found to be in contact with the transmitting tissue, which facilitated the penetration of the pollen tube into the micropyle.

The anatropous and bitegmic ovules seemed to be characteristic for Trichilia species, as recorded in the literature (Beltrati, 1984; Beltrati and Brunini, 1988, Moscheta, 1995 and Boesewinkel, 1981). According to Boesewinkel (1981), the ovule of $T$. grandifolia Oliv. is crassinucellate. According to Davis (1966), the use of the terms crassinucellate and tenuinucellate have been generating a lot of confusion in the botanical literature. Therefore, she introduced pseudocrassinucellate. According to her, crassinucellate should be limited to the ovule, in which the archesporial cell divides forming a primary parietal cell which does or does not divide, while pseudocrassinucellate should be used for ovules, where no the parietal cells are formed; but the apical cells of the nucellar epidermis undergo periclinal divisions giving rise to a nucellar cap. Thus, an ontogenetic study of the nucellar development of the species would be necessary to be able to affirm if the ovules are crassinucellate or pseudocrassinucellate.

The synergids of the studied species presented their respective filiform apparatus well-defined at the basal end of the cell. Kapil and Bhatnagar (1981) present several filiform apparatus shapes for several Angiosperm species and attribute several functions to this structure, such as absorption, nutrient synthesis and transport, glandular nature and an important role in the penetration and effusion of the pollen tube, with the consequent diffusion of spermatic cells to the egg and the central cell (polar nuclei).

In several taxa one of the synergids can survive after the fertilization, becoming hypertrophic, polyploid or multinucleate and to exercising a haustorial function - absorbing, storing or secreting nutrients necessary for the zygote and the young pro embryo (Kapil and Bhatnagar, 1981). It seemed that in T. catigua the two synergids degenerated. This is confirmed by the analysis of Moscheta (1995).

\section{RESUMO}

As características morfológicas e anatômicas das flores de Trichilia catigua A. Juss., T. elegans A. Juss. e T. pallida Sw. (Meliaceae) são descritas no presente trabalho, visando subsidiar futuros estudos sobre reprodução e preservação destas espécies nativas. A antese ocorreu de abril a agosto em T. catigua, de janeiro a maio em $T$. pallida e setembro a janeiro em $T$. elegans. As sépalas e pétalas apresentavam epiderme papilosa e pilosa e mesofilo parenquimático. As flores masculinas possuiam pistilódio com óvulos abortivos e tubo estaminal com número variável de anteras tetrasporangiadas, cuja parede apresentava epiderme papilosa, endotécio, duas camadas médias e tapete secretor. As flores femininas apresentavam anteródios e pistilo bi ou tricarpelar, com ovário de estrutura simples, estilete oco ou sólido com tecido transmissor central e estigma com pêlos uni ou bicelulares. Os óvulos eram anátropos e bitegumentados. Não foram encontrados no ambiente de estudo exemplares das espécies estritamente dióicos, sendo todos em maior ou menor grau monóicos. 


\section{REFERENCES}

Aegthe, C. (1951), Uber die physiologische Herkunft des Pflanzennektars. Ber. schweiz. bot. Ges. 61, 240-277.

Beltrati, C. M. (1984), Morfologia e anatomia das sementes de Trichilia elegans A. Juss. (Meliaceae). Naturalia 9, 35-42.

Beltrati, C. M. and Brunini, J. (1988), Morfologia, anatomia e desenvolvimento das sementes e plântulas de Trichilia pallida Swartz (Meliaceae). R. bras. Biol. 48, 673-681.

Berlyn, G. P. and Miksche, J. P. (1976), Botanical Microtechnique and Cytochemistry. The Iowa State University Press, Ames, Iowa.

Boesewinkel, F. D. (1981), Development of the seed of Trichilia grandifolia Oliv. (Meliaceae). Acta Bot. Neerl. 30, 459-464.

Campos, J. B. (1997), Análise dos desflorestamentos, estrutura dos fragmentos florestais e avaliação do banco de sementes do solo da ilha de Porto Rico na planície de inundação do Alto Rio Paraná, Brasil. Tese de doutorado, Universidade Estadual de Maringá, Maringá, Brasil.

Carr, S. G. M. and Carr, D. J. (1961), The functional significance of syncarpy. Phytomorphology 11(3), 249-256.

Davis, G. L. (1966), Systematic Embryology of the Angiosperms.John Wiley and Sons, New York

Heslop-Harrinson, Y. and Shivanna, K. R. (1977), The receptive surface of angiosperm stigma. Ann. Bot. 41, 1233-1258.

Ipardes (1992), Diagnóstico para a implantação de políticas para o setor florestal no Paraná. Fundação Ipardes, Curitiba.

Johansen, D. A. (1940), Plant Microtechnique. McGraw-Hill, New York.

Kapil, R. N. and Bhatnagar, A. K. (1981), Ultrastructure and biology of female gametophyte in flowering plants. Int. Rev. Cytol. 70, 291-341.
Klein, R. M. (1984), As plantas Meliáceas. In-Flora Ilustrada Catarinense, ed. R. Reitz. Herbário Barbosa Rodrigues, Itajái, Santa Catarina, 9-65.

Moscheta, I. S. (1995), Morfologia e desenvolvimento dos frutos, sementes e plântulas de Cabralea canjerana (Vell.) Mart., Guarea kunthiana A. Juss. e Trichilia catigua A. Juss. (Meliaceae - Melioideae). Tese de doutorado, Universidade Estadual Paulista, Rio Claro, Brasil.

Opler, P. A. (1983), Nectar production in a tropical ecosystem. In - The Biology of Nectaries, B. Bentley and T. Elias. Columbia University Press, New York, 259p.

Opler, P. and Bawa, K. S. (1978), Sex ratios in tropical forest trees. Evolution, 32, 812-821.

Pennington, T. D. (1981), A monograph of neotropical Meliaceae. Flora Neotr., 28, 1-449.

Puentes, D. A., Hernandes-de-Armas, J. and LopezAlmiral, A. (1993), Phenology and floral structure of Trichilia havanensis Jacq. (Meliaceae). Ann. Miss. bot. Gdn. 80, 862-869.

Ruetze, M. and Schmitt, V. (1986), Glykol-methacrylat (GMA) als Einbettungssystem in histologische Untersuchungen von Koniferen-Nadeln. Eur. J. Forest Path. 16, 321-324.

Styles, B. T. (1972), The flower biology of the Meliaceae and its bearing on tree breeding. Silvae Genet., 21, 175-182.
Received: October 31, 2000; Revised: January 05, 2001; Accepted: April 27, 2001. 